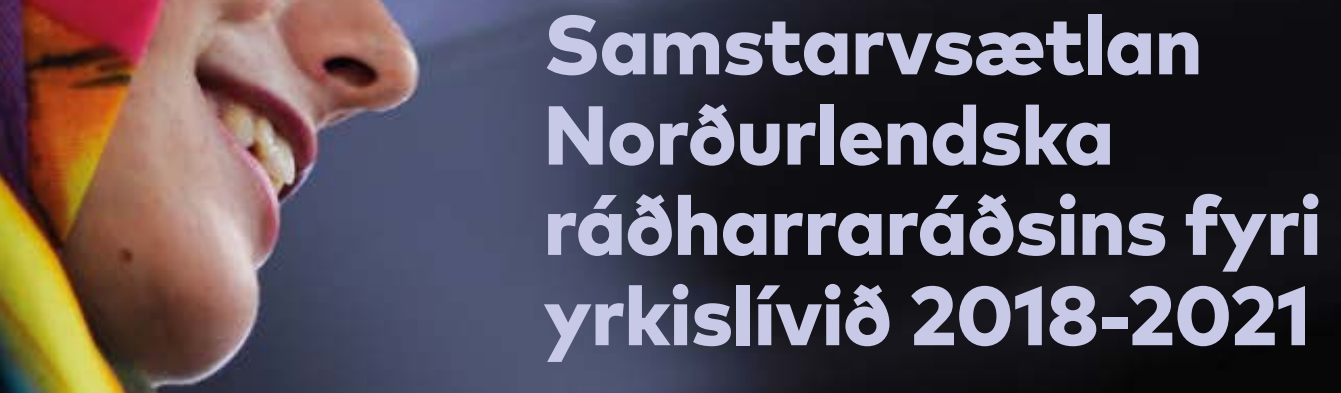

Iㅛ Norỗurlendska Ráôhharraráồiô 


\section{Samstarvsætlan Norðurlendska ráoharraráðsins fyri yrkislívið 2018-2021}

ANP 2018:715

ISBN 978-92-893-5469-1 (PRINT)

ISBN 978-92-893-5470-7 (PDF)

ISBN 978-92-893-5471-4 (EPUB)

http://dx.doi.org/10.6027/ANP2018-715

(c) Norðurlendska ráðharraráðið 2018

Sniðgáva: Gitte Wejnold

Kápumynd: Unsplash.com

Prent: Rosendahls

Printed in Denmark

\section{Norðurlendska samstarvið}

Norðurlendska samstarvið er eitt tað víðfevndasta økissamstarvið í heiminum. Samstarvið fevnir um Danmark, Finnland, Ísland, Noreg og Svøríki og Føroyar, Grønland og Áland.

Norðurlendska samstarvið er politiskt, búskaparliga og mentanarliga kjølfest, og tað er týðandi partur í evropiskum og altjóða samstarvi. Norðurlendski felagsskapurin virkar fyri sterkum Norðurlondum í einum sterkum Evropa.

Norðurlendska samstarvið vil styrkja áhugamál og virði hjá Norðurlondum á øllum økjum í einum altjóðagjørdum umheimi. Felags virði landanna millum eru við til at styrkja støðu Norðurlanda sum eitt av heimsins mest nýhugsandi og kappingarførastu økjum.

\section{Norðurlendska ráðharraráðið}

Nordens Hus

Ved Stranden 18

1061 København $\mathrm{K}$

www.norden.org

Tak niður norðurlendskar útgávur: www.norden.org/nordpub 


\section{Samstarvseatlan Norôurlendska ráôharraróôsins fyri yrkislívio 2018-2021}




\section{Innihald}

Um samstarvsætlan Norðurlendska ráðharraráðsins 6

Um samstarvsætlanina fyri yrkislivið 7

Átaksøki 8

Átaksøki 1

Átaksøki 2

Átaksøki $3 \quad 12$

Átaksøki 4

Samstarv við ES og aðrar altjóða leikarar 17

Samskipan á økinum 18

Lærdi háskúlin fyri arbeiðsumhvørvi - NIVA 20

Samstarvsætlanin framd í verki 22 


\section{Um samstarvsætlan Norðurlendska ráoharrarádsins}

Samstarvsætlan Norðurlendska ráðharraráðsins fyri Yrkislív (MR-A)

lýsir tær týdningarmestu politisku avbjóðingarnar og raðfestingarnar á økinum fyri tíðarskeiðið 2018-2021. Endamálið við samstarvsætlanini er at áseta ta politisku kósina fyri formliga norðurlendska stjórnarsamstarvið. Ættanin gevur eina heildarlýsing av $ø$ øjum, har farast kann undir ítøkilig átøk og verkætlanir. Samstarvið um yrkislívið fevnir um Norðurlond, íroknað Føroyar, Grønland og Áland, og viðger yrkislívið, arbeiðsmarknaðarøkið og arbeiðsumhvørvis- og arbeiðsrættarøkið.

Samstarvsætlanin hevur stýrandi virknað á økinum og skal fylgjast saman við øðrum skipanarskjølum í norðurlendska samstarvinum. Samstarvsætlanin stuðlar sjónarmiðinum hjá norðurlendsku forsætisráðharrunum i 2016 um at gera Norðurlond til mest samansjóðaða økið í heiminum og visjónini hjá norðurlendsku ráðharrunum, „Saman standa vit sterkari", sum varð samtykt i 2014. Fjøltáttaðu virkisskráirnar hjá Norðurlendska ráðharraráðnum viðvíkjandi javnstøðu, burðardyggari menning, børnum og ungum, samansjóðing og førleikatarni - skulu eisini setast inn í ætlanina.

I 2016 gjørdi fyrrverandi danski ráðharrin og ES-kommiserurin Poul Nielson eina gjølliga kanning av yrkislívinum vegna MR-A. Úrslitini frá kanningini vórðu savnað i frágreiðing við heitinum "Yrkislív í Norðurlondum - avbjóðingar og uppskot", sum varð viðgjørd á fundi hjá MR-A í november 2016. Evnini, greiningarnar og uppskotini í frágreiðingini umframt niðurstøðurnar frá fundinum hjá MR-A eru ein týðandi partur av grundarlagnum fyri hesa samstarvsætlan.

Í sambandi við felags avbjóðingar leggur samstarvið innan yrkislívið stóran dent á at kanna, greina og samskifta um tiltøk, úrslit og royndir, sum kunnu vera lík ella ólík i ymsu Norðurlondunum. Samstarvið kann veita íblástur til at menna innlendis politikk í teimum einstøku londunum, men eisini umstøður til at samskipa sjónarmið í málum, har londini kunnu røkka betri úrslitum í felag enn hvør sær treytað av, at ein slík samskipan er viðkomandi og Norðurlondum at gagni. 
UM SAMSTARVSAETLANINA FYRI YRKISLÍVIĐ

Yrkislívið hevur ein avgerandi leiklut í menningini av norðurlendsku vælferðarsamfeløgunum, í vinnulívinum og fyri hvønn einstakan. Felags arbeiðsmarknaðurin er ein hornasteinur i norðurlendska samstarvinum. Ein stór og væl útbúgvin arbeiðsmegi er týdningarmesta tilfeingi okkara, sum leggur lunnar undir ein kappingarføran norðurlendskan arbeiðsmarknað eins og menningina av norðurlendsku vælferðarsamfeløgunum. Norðurlond skara framúr í altjóða høpi, tí bæði kvinnur og menn eru væl útbúgvin.

Á norðurlendska arbeiðsmarknaðinum standa tó nógvar broytingar fyri durum sum avleiðing til dømis av broytingum í fólkasamansetingini, øktari altjóðagerð, tøkni og altjóða kapping. Skjóta tøkniliga menningin hevur avleiðingar fyri eftirspurning, førleikakrøv, skipan og innihald íyrkislívinum. Við menningini koma nógvir nýggir møguleikar, men stórar avbjóðingar kunnu eisini fylgja við.

Samstarvsætlanin fyri yrkislívið 2018-2021 vísir á mangar týðandi avbjóðingar á økinum og lýsir, hvønn leiklut norðurlendska samstarvið kann hava, tá ið tikið verður við hesum avbjóðingum. Samstarvsætlanin orðar umráðandi fortreytir fyri norðurlendska samstarvinum um yrkislívið. ÆEtlanin lýsir mál og greiðsluevni, ið fáa avgerandi leiklut fyri samskifti og ráðgeving landanna millum, og sum verða grundarlagið fyri samskipan av vitan og royndum í fýra-áraskeiðnum.

Einstøku stjórnirnar í Norðurlondum arbeiða allar miðvíst við at skapa eitt vælvirkandi yrkislív og ein burðardyggan vøkstur og arbeiði. Gjøgnum norðurlendska samstarvið fáa stjórnirnar hentar upplýsingar og íblástur til hetta arbeiðið.

Undir ætlanarskeiðnum fer samstarvið um yrkislivið at leggja størstan dent á hesi átaksøki:

- Fáa betri samsvar millum útboð og eftirspurning av skikkaðari arbeiðsmegi umframt at økja um luttøkuna á arbeiðsmarknaðinum, serliga hjá fólki í vandabólkum.

- Skapa gott arbeiðsumhvørvi fyri bæði kvinnur og menn til dømis við at fyribyrgja arbeiðsskaða og -sjúku og við at beina fyri vánaligum arbeiðskorum.

- Tryggja eina góða javnvág millum starvsfólkavernd og smidleika umframt at verja tann trítáttaða norðurlendska arbeiðsfrymilin.

- Fáa betri samansjóðing, somu møguleikar og frælsi at reika á norðurlendska arbeiðsmarknaðinum.

Samstarvsætlanin varð samtykt hin 28. november 2017. Hon fær gildi 1. januar 2018 og er í gildi til ársenda 2021. 


\section{Átaksøki}

Samstarvið um yrkislívið fer í núverandi fýra-áraskeiði at raðfesta langtíðar avbjóðingar og møguleikar, ¡ð standa fyri durum á norðurlendska arbeiðsmarknaðinum. Summar av avbjóðingunum, ið standa fyri framman, eru avleiðingar av altjóðagerðini á arbeiðsmarknaðinum, talgildingini, vaksandi býtisbúskapinum og teirri ávirkan, tey hava á starvssetanarhættir, skipan av fakfeløgum og arbeiðskor. Sjálvvirkandi maskinur og robottar hava við sær, at arbeiðspláss hvørva ella broytast. Í miðdeplinum eru avbjóðingar, ið standast av breiðkandi gjáum, láglønarkapping og øktari afturúrsigling umframt avbjóðingar í sambandi við atgongd til førleikamenning og hægri lesnað gjøgnum alt arbeiðslívið. Í sambandi við luttøku á abeiðsmarknaðinum er framvegis tørvur á at geva fólki í vandabólkum serligan ans, og áhaldandi tilflytingin til Evropa krevur eisini munagóða samansjóðing. Millum avbjóðingarnar hjá Norðurlondum er at fáa ein fjølbroyttari luttakaraskara av tilflytarum á arbeiðsmarknaðin. Eldra ættarliðið heldur seg alsamt longur framat á arbeiðsmarknaðinum, men tað er samstundis ein avbjóðing at tryggja eitt nøktandi útboð av arbeiðsmegi umframt at nøkta vaksandi tørvin á vælferðartænastum í Norðurlondum. Hetta er serliga galdandi á økjum, har fólkið í arbeiðsførum aldri fækkast.

Norðurlendska samstarvið leggur dent á langtíðaravbjóðingar. Samstarvið hevur tó eisini ávíst rúm fyri hissini avbjóðingum, ið kunnu standast av príslagsbroytingum og øðrum, ið ilt er at spáa um, men sum kann koma fyri hetta skeiðið.

Tær avbjóðingar og tey broytingarrák, ¡ð eru í væntu, eru á mangan hátt samantvinnað og tí torfør at býta sundur í ítøkilig øki. Samanumtikið kann sigast, at norðurlendski arbeiðsmarknaðurin er komin í eina støðu, sum kann hava stóra ávirkan á framtíðar yrkislív og samfelag. Tískil kann tað vera ein fyrimunur at taka við hesum avbjóðingum ígjøgnum norðurlendska samstarvið. Framhaldsviðgerð og samstarv við víðari og betur samansjóðaðum frágreiðingum, hagtølum og nútímans forsagnum kunnu vera íkast til hetta arbeiðið saman við áhaldandi samskifti um royndir, fakligt og politiskt orðaskifti og sínámillum læring í Norðurlondum. 


\section{ÁTAKSøKI 1}

Fáa betri samsvar millum útboð og eftirspurning av skikkaðari arbeiðsmegi umframt at økja um luttøkuna á arbeiðsmarknaðinum, serliga hjá fólki í vandabólkum.

Ein av fremstu raðfestingunum í samstarvinum innan yrkislívið og arbeiðsmarknaðarøkið er at fáa so stóra luttøku á arbeiðsmarkanaðinum sum gjørligt av bæði kvinnum og monnum umframt at fáa fólkini, ið støðugt standa uttan fyri arbeiðsmarknaðin, at vera so fá sum gjørligt.

Týðandi mál innan yrkislívið og arbeiðsmarknaðarøkið:

\section{Økja um luttøkuna á arbeiðs-} marknaðinum, serliga hjá fólki í vandabólkum. Hetta krevur, at dentur verður lagdur á eina skjótari og munabetri samansjóðing av til dømis ungum, langtíðartøkum, eldra ættarliðnum og tilflytarum á arbeiðsmarknaðinum. Harumframt verður dentur lagdur á at minka um sjúkrafráveru hjá starvsfólki og at økja um luttøkuna hjá fólki við skerdum arbeiðsføri og førleikatarni. Neiliga gongdin innan sálarheilsu, serliga hjá ungum, er ørkymlandi og krevur ans.
Tað er umráðandi at tryggja, at tey, ið fáa eitt starv, megna at varðveita tað, og at eldra ættarliðið verður verandi á arbeiðsmarknaðinum so leingi sum gjørligt. Luttøkan á arbeiðsmarknaðinum skal eisini økjast soleiðis, at tey, ið arbeiða parttíð og vilja arbeiða meira, skulu fáa møguleika til tess. Fyri at røkka hesum máli er neyðugt við ráðførslu og samstarvi við ymiskar viðkomandi leikarar á arbeiðsmarknaðinum.

\section{Fáa betri samsvar millum útboð} og eftirspurning av arbeiðsmegi. Dentur verður lagdur á at greiða, hvussu betri samsvar kann fáast á arbeiðsmarknaðinum við tí endamáli at beina fyri fløskuhálsum og tryggja betri gagnnýtslu av arbeiðstilfeinginum. At arbeiðstakarar finna rætta arbeiðsgevara og øvugt er treytað av, at arbeiðsloysisskipanin hevur gott innlit í tørvin á arbeiðsmarknaðinum og samband við bæði arbeiðstakara og arbeiðsgevara. Tað er framvegis ein fyrimunur at hava góðkenda útbúgving og viðkomandi førleikar. Somuleiðis er tað gott at vera fakliga smidligur og landafrøðiliga óheftur, og harumframt verður væntað, at hvør einstakur er íðin og kýtir seg.

Dentur verður lagdur á at basa

arbeiðsloysi, økja um yrkismøguleikar og 


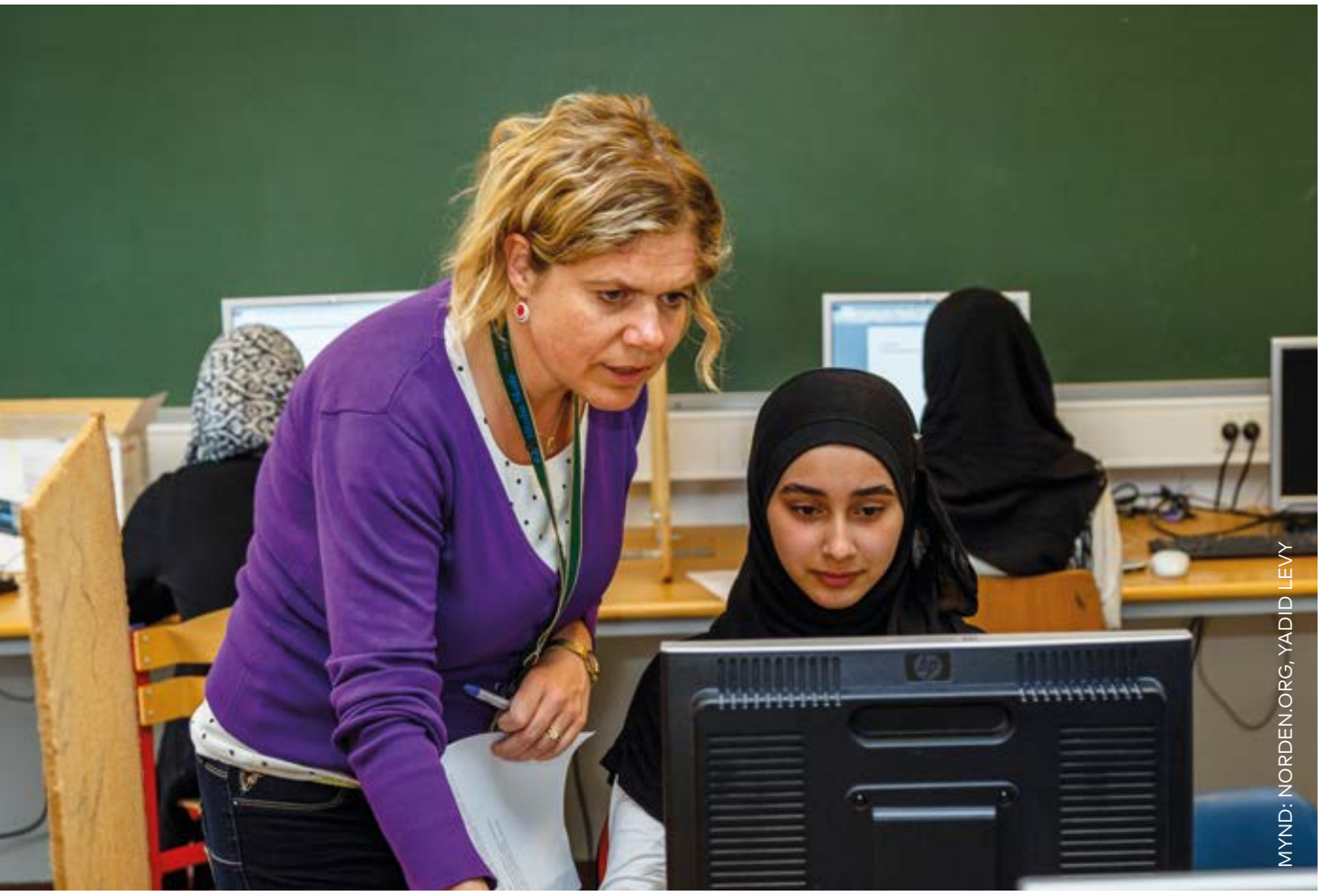

forða langtíðar arbeiðsloysi. Ungdómar, tilflytarar og fólk við avmarkaðum formligum førleikum eru dømi um samfelagsbólkar í serligum vanda fyri at gerast arbeiðsleys. Fólk við førleikatarni, ¡ð elvir til skerdar arbeiðsførleikar, enda ofta arbeiðsleys, hóast tey fegin vilja sleppa til arbeiðis. Sjóneykan verður sett á førleikatarn, ið forðar hesum bólki at vera við í yrkislívinum, og á munagóð tiltøk at fáa fleiri teirra til arbeiðis. Í hesum sambandi er eisini umráðandi at kanna, hvussu forðingar á arbeiðsmarknaðinum kunnu skerjast og møguleikar økjast, hvussu áhugi fyri arbeiði kann skapast, og hvussu ein góð javnvág millum arbeiði, inntøku og vælferðartænastur kann røkkast í Norðurlondum.

\section{Stuðla førleikamenning, ið er lagað eftir} tørvinum á arbeiðsmarknað̃inum. Dentur skal leggjast á, hvussu vit á besta hátt mega førleikamenna arbeiðsmegina til tess at nøkta vaksandi tørvin á umlegging umframt at tryggja, at førleikar hjá arbeiðsmegini verða mentir so hvørt, sum arbeiðsmarknaðurin krevur tað. Tørvurin á førleikamenning er serliga stórur hjá fólki við ongari hægri formligari útbúgving og við avmarkaðum grundleggjandi førleikum og hjá fólki við førleikum, ið ikki samsvara við tørvin á arbeiðsmarknaðinum. Hesir bólkar eru 
serliga viðkvæmir, tá ið broytingar og umleggingar verða gjørdar í yrkinum, til dømis í sambandi við tøkniliga menning. Útbúgvingarskipanin má eisini verða tillagað til at veita hægri grundleggjandi útbúgving og tryggja, at serliga ungdómurin fær nøktandi skúlagongd. Samstundis noyðast flest vaksin at menna sínar førleikar javnan fyri at fylgja við skiftandi krøvum á arbeiðsmarknaðinum - uttan mun til aldur, kyn og útbúgving. Tí er neyðugt at seta sjóneykuna á lívslanga læru, læru í yrkislívinum og starvinum og á møguleikarnar fyri eftirútbúgvingum.

\section{ÁTAKSøKI 2}

Skapa gott arbeiðsumhvørvi fyri bæði kvinnur og menn til dømis við at fyribyrgja arbeiðsskaða og -sjúku og við at beina fyri vánaligum arbeið̌skorum.

Týðandi mál á arbeiðsumhvørvisøkinum:

Virka skipað og miðvíst fyri góðum arbeiðsumhvørvi. Við broytingum í fólkasamansetingini og vaksandi tørvi á arbeiðsmegi er neyðugt at leggja dent á fyribyrgjandi arbeiði í arbeiðsumhvørvinum hjá virkjum og fyritøkum. Eitt skipað og miðvíst arbeiði í nærumhvørvinum við støði í virksemi og framleiðslu hjá einstøkum virkjum, ið slóðar fyri einum arbeiðsumhvørvi, har starvsfólk fáa arbeitt skjótt og væl uttan vanda fyri skaða og sjúku, er avgerandi, um sjúkrafrávera skal minka, yrkislívið leingjast og luttøkan í yrkislívinum hjá fólki í vandabólkum økjast. Tað er umráðandi at betra um møguleikarnar hjá barnafamiljum og støkum at finna størv við betri javnvág viðvíkjandi privatlívinum umframt at stuðla eldra ættarliðnum at verða verandi longur á arbeiðsmarknaðinum. Til tess at røkka hesum málum er tørvur á meiri vitan um neyðugar stuðulskipanir og eftirkanningar á einstøku arbeiðsplássunum og einstøka arbeiðsumhvørvinum. Stórur munur er á arbeiðsháttum hjá ymsu virkjunum, og tí er óivað pláss fyri ábótum á økinum. Ein betri fatan av, hvussu umhvørvið ávirkar arbeiðsavrik, og hvørji átøk best kunnu minka um sjúkrafráveru og fyritíðareftirløn, er av størsta týdningi.

\section{Virka fyri einum góðum kropsligum og} sálarligum arbeiðsumhvørvi. Dentur skal leggjast á at kanna, hvussu hvørt einstakt starvsfólk best fær varðveitt styrki og heilsu, og hvussu eitt gott og burðardygt arbeiðsumhvørvi kann tryggjast øllum starvsfólkum alla teirra yrkisleið. Sjóneykan verður sett á stóru avbjóðingarnar, ið til dømis 
síggjast í hagtølunum um sjúkrafráveru og fyritíðareftirløn, har vødda- og beinagrindssjúkur umframt sálarligir og sosialir trupulleikar eru stóru syndararnir. Harumframt skal sjóneykan eisini verða sett á vandabólkar, til dømis ungdóm og eldra ættarliðið, minnilutabólkar og fólk við skerdum arbeiðsførleikum umframt serliga krevjandi yrki og vinnugreinar. Arbeiðsumhvørvisætlanin hjá ES verður eisini nýtt til at leggja støðið undir norðurlendska samstarvið á hesum økinum.

\section{Beina fyri ússaligum arbeiðskorum og} lønarmismuni. Dentur skal leggjast á at kanna, hvussu Norðurlond kunnu gerast ein dragandi arbeiðsmarknaður við høgum førleikastøði og góðum arbeiðskorum og -umhvørvi, sum kann lokka ta útlendsku arbeiðsmegina, sum vit ynskja okkum, higar. Samstundis verður áherðsla løgd á at fyribyrgja, at økt innflutt arbeiðsmegi og láglønarkapping førir til ússalig arbeiðskor, lønar- og annan mismun á norðurlendska arbeiðsmarknaðinum. Á hesum økinum er nógv tilfar, ið kann verða býtt landanna millum bæði av upplýsingum og royndum viðvíkjandi munadyggum fyribyrgjandi átøkum og amboðum at steðga lógarbrotum, og eitt víðkað samstarv millum viðkomandi norðurlendsku myndugleikarnar er vert at hugsa um í hesum máli.

\section{Framhaldandi menning av} arbeiðsumhvørvisætlanum og -eftirliti. Dentur skal leggjast á sínámillum umbýti av royndum og vitan um munadyggar arbeiðsumhvørvisætlanir og eftirlitshættir, herímillum arbeiðsumhvørvisætlanina og aðrar viðkomandi raðfestingar hjá ES. Ein týðandi partur av arbeiðinum er málið at fáa meiri ítøkiliga og gagnliga granskingargrundaða vitan um, hvørjar arbeiðsumhvørvisætlanir og hvørjir eftirlitshættir hava jaliga ávirkan og geva úrslit á virkjunum.

\section{ÁTAKSøKI 3}

Tryggja eina góða javnvág millum starvsfólkavernd og smidleika umframt at verja tann trítáttaða norðurlendska arbeiðsfrymilin.

Arbeiðsumhvørvis- og arbeiðsrættarøkið eru tætt knýtt hvørt at øðrum, og tí er umráðandi at hyggja at málunum undir átaksøki 2 og 3 saman. Týðandi mál, ið kunnu betra arbeiðsrættarøkið, eru: 


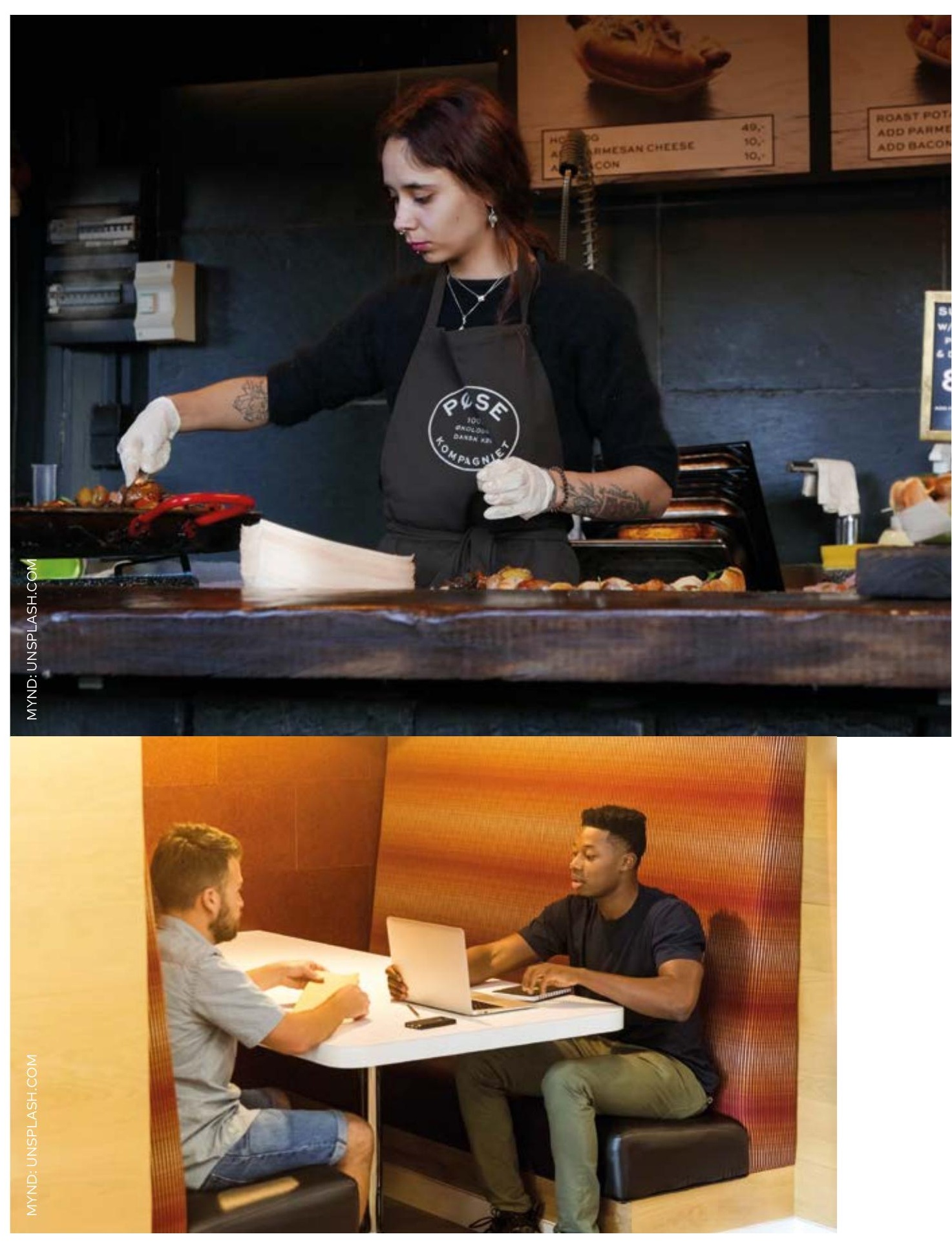


Tryggja eina góða javnvág millum starvsfólkavernd og smidleika í

yrkislívinum. Framtíðar yrkislív bjóða

nýggjar arbeiðshættir og nýggjar

arbeiðsuppgávur. Nýggju hættirnir

at skipa yrkislívið fara at ávirka

arbeiðsrættarligu starvssetanarhættirnar

og viðurskiftini, og tí verður umráðandi

at tryggja, at hetta ikki fær neiligar

fylgjur fyri tann einstaka, fyri virki ella

fyri samfelagsbúskapin. Nýggj orka

skal leggjast í at menna skipanir, ið kunnu tryggja eina javnvág millum arbeiðstakaravernd og smidleika í

yrkislívinum.

\section{Tryggja skipaðar umstøður á}

arbeiðsmarknaðinum. Dentur skal

leggjast á at varðveita og menna eitt

dygdargott yrkislív í Norðurlondum og at samstarva við ymsu partarnar á arbeiðsmarknaðinum um at fyribyrgja lønar- og annan mismun og gráan búskap.

\section{Tillaga og menna norðurlendska} arbeiðsfrymilin. Trítáttaði arbeiðsfrymilin er lívæðrin í Norðurlondum. Tí verður raðfest at greina, hvussu frymilin kann verjast og mennast gjøgnum norðurlendska samstarvið við at býta um vitan og annað samskifti til dømis við sambandinum við ES og aðrar viðkomandi pallar. Harumframt er málið at tryggja kappingarføri og burðardygd í hesum frymli mótvegis øðrum arbeiðsfrymlum. Skipan av fakfeløgum umframt støða og styrki hjá ymsu pørtunum á norðurlendska arbeiðsmarknaðinum hava eisini sín týðandi leiklut her.

\section{ÁTAKSøKI 4}

Fáa betri samansjóðing, eins møguleikar og frælsi at reika á norðurlendska arbeiðsmarknað̌inum.

Týðandi fjøltáttað mál á hesum øki:

Tryggja samansjóðing fyri tilflytarar. Ígjøgnum samstarvsætlanarskeiðið skal serligur dentur leggjast á tiltøk, ið tryggja støðugt arbeiði, tí virkni er ein av grundleggjandi fortreytunum fyri einari væleydnaðari samansjóðing, eins og tað er ein týdningarmikil liður í at tryggja burðardygd í vælferðarskipanunum. Tørvur er á at tryggja eina skjóta og lætta leið inn í yrkislívið. Ein munagóður samansjóðingarpolitikkur krevur alt frá, at tilflytarar eru við í tiltøkum, ið veita teimum førleikar at finna seg til rættis á arbeiðsmarknaðinum og í samfelagnum, til samskifti við ymisku partarnar á 
arbeiðsmarknaðinum og sjálvbodnar felagsskapir umframt samstarv millum tað almenna og privata. Eisini er umráðandi fyri samansjóðingina hjá børnum og ungum, at bæði foreldrini eru við í yrkislívinum.

\footnotetext{
Virka fyri javnviðgerð og javnstøðu í

yrkislívinum. Samstarvið um yrkislívið skal fremja javnviðgerð við atliti at kyni, uppruna, førleikatarni o.s.fr. umframt at fyribyrgja sundurbýttum arbeiðsmarknaðum. Her kemur javnvágin millum yrkislív og privatlívi miðdepilin. Í hesum sambandi er eisini umráðandi at betra um møguleikarnar hjá tilfluttum kvinnum at koma á arbeiðsmarknaðin og at seta tiltøk í verk, ¡ð gera tað lættari at samskipa arbeiði, útbúgving og familju. Samstarvið um yrkislívið fer harumframt at virka ímóti mismuni vegna aldur, kyn, uppruna, tjóðskap o.s.fr.
}

Frælsi at reika umframt at minka og fyribyrgja marknaforðingum í Norðurlondum. Fríi norðurlendski arbeiðsmarknaðurin hevur virkað væl í meir enn 60 ár, og tað er umráðandi at varðveita og menna hann frameftir. Arbeiðið á hesum økinum leggur áherðslu á støðugt at betra møguleikarnar at reika frítt á norðurlendska arbeiðsmarknaðinum við at skerja verandi marknaforðingar og fyribyrgja, at nýggjar stinga seg upp. Hetta arbeiðið verður gjørt við atliti at ES og teimum kørmum, ið ES hevur sett. Tað er umráðandi at undirstrika tann týdning, ¡ð fría reikingin hevur, serliga fyri fáment øki og teirra avbjóðingar, sum til dømis standast av ójavnvág í førleikatørvi. 


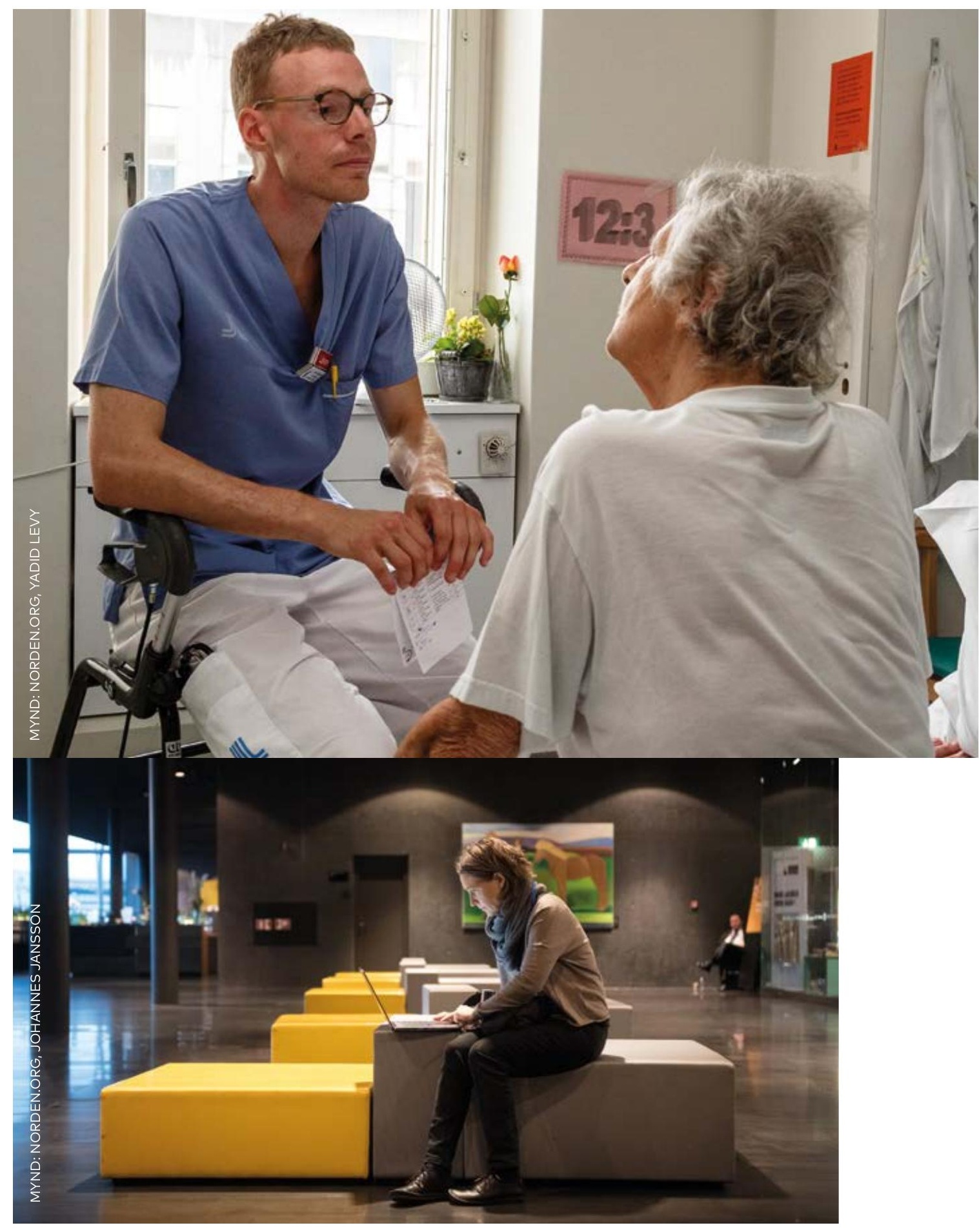




\section{Samstarv við ES og að̆rar altjóða leikarar}

$\varnothing k i ð$ fer áhaldandi at virka fyri at styrkja samstarvið við ES og fylgja við uppskotum, ið koma frá Evropakommissjónini. ES-málsøki, ið eru viðkomandi fyri Norðurlond sum heild, verða viðgjørd so hvørt á fundum í ráðharraráðnum, tænastumannanevndini og øðrum nevndum. Ein týðandi partur av hesum arbeiðinum er at skerja verandi marknaforðingar so nógv, sum til ber og at fyribyrgja, at nýggjar stinga seg upp.

Serliga er tað Arbeiðsrættarnevndin, ¡ð tekur sær av ES-málsøkjum, og hon fylgir við bæði tíðliga í lóggávuskeiðnum, undir viðgerðunum, og tá ið ESlógir verða samtyktar, umframt við avgerðum hjá ES-dómstólinum og øðrum líknandi málum. Harumframt hevur Tænastumannanevndin fyri Yrkislívið (EK-A) biðið norðurlendska almannatryggingarbólkin um at fylgja gongdini á omanfyri nevndu økjum fyri at fyribyrgja, at nýggjar marknaforðingar stinga seg upp.

ES-kunningarbólkurin fyri Norðurlond, Baltalond og Póland fylgir arbeiðinum hjá ES viðvíkjandi yrkispolitikki.
Umframt ES eru mangir aðrir altjóða leikarar, ið hava týdning fyri norðurlendska samstarvið um yrkislívið. Altjóða yrkisfelagsskapurin (ILO) er yrkisfelag hjá ST fyri yrkis- og arbeiðsumhvørvi. Tað er umráðandi, at samstarvsætlanin fyri yrkislívið til dømis leggur fyri við at fylgja og ávirka arbeiðið, ið verður gjørt við Future of Work, sum er partur av 100-árahátíðarhaldinum hjá ILO í 2019. Til hetta hátíðarhald verður høvi hjá Norðurlondum, íroknað Føroyum, Grønlandi og Álandi, at vera við og vísa á norðurlendsk sjónarmið og royndir viðvíkjandi framtíðar útlitum fyri yrkislívið, og hetta fer eisini at leggja lunnar undir framhaldandi samstarv.

Felagsskapurin fyri Búskaparligt Samstarv og Menning (OECD) leggur stóran dent á tiltøk, ið skapa vøkstur og arbeiði. Yrkisvitanin og greiningarnar hjá OECD av málsøkjum, ið viðvíkja arbeiðsmarknaðinum, kunnu vera ískoyti til norðurlendska samstarvið um yrkislívið.

Til ávís viðkomandi høvi verða umboð fyri til dømis ES, OECD og ILO boðin við til fundir, ráðstevnur o.a. 


\section{Samskipan á økinum}

Norðurlendska ráðharraráðið fyri

Yrkislívið (MR-A) hevur yvirskipaðu

ábyrgdina av norðurlendska

samstarvinum um yrkislívið og verður ein

týdningarmikil pallur fyri norðurlendsku

ráðharrarnar í yrkis-, arbeiðsrættar-og

arbeiðsumhvørvismálum at kjakast

á, kunna um royndir og samskifta

um, hvussu takast skal ímóti felags

avbjóðingum á økinum.

Samstarvið verður samskipað av Norðurlendsku tænastumannanevndini fyri Yrkislívið (EK-A), sum ásetur leiðreglur fyri og býtið av fíggjarjáttanini hjá MR-A. Ein smidligur bygnaður er avgerandi fyri, at norðurlendska samstarvið um yrkislívið kann fara undir og fylgja við í viðkomandi málum.

EK-A hevur sett tríggjar fastar nevndir - Arbeiðsmarknaðarnevndina, Arbeiðsumhvørvisnevndina og Arbeiðsrættarnevndina - og setur síðani ad-hoc nevndir eftir tørvi. Umframt nevndirnar fevnir samstarvið um ESkunningarbólkin fyri Norðurlond, Baltalond og Póland, hvørs høvuðsendamál er at viðgera arbeiðsmarknaðarpolitikkin, yrkislóggávu og arbeiðsumhvørvismál hjá ES.

Nevndirnar og arbeiðsbólkarnir hava ein týðandi leiklut í sambandi við vitanar- og royndarumbýtið landanna millum á teirra avvarandi ábyrgdarøkjum. Harumframt geva tey eisini sítt íkast til MR-A og EK-A.

Norðurlendski lærdi háskúlin fyri arbeiðsumhvørvi (NIVA) í Helsingfors tekur eisini lut í norðurlendska samstarvinum fyri yrkislívið, sí síðu 20. Harumframt fíggjar MR-A partvíst Nordjobb, sum hjálpir norðurlendskum ungdómi, ið hevur hug at starvast í einum øðrum norðurlandi enn sínum heimlandi (www.nordjobb.net). MR-A fíggjar eisini eitt kunningarátak um norðurlendska yrkislívið á skandinaviskum og enskum (www.arbejdslivinorden.org).

Harumframt skapar formliga samstarvið týdningarmikil netverk millum norðurlendskar myndugleikar í yrkislívinum, sum londini kunnu fáa stóran og ítøkiligan ágóða av. Viðmerkjast skal, at eitt víðfevnt óformligt norðurlendskt samstarv, sum í nógvum førum hevur nógv ár á baki, eisini blómar innanhýsis í Norðurlendska ráðharraráðnum við síðuna av tí formliga samstarvinum. 

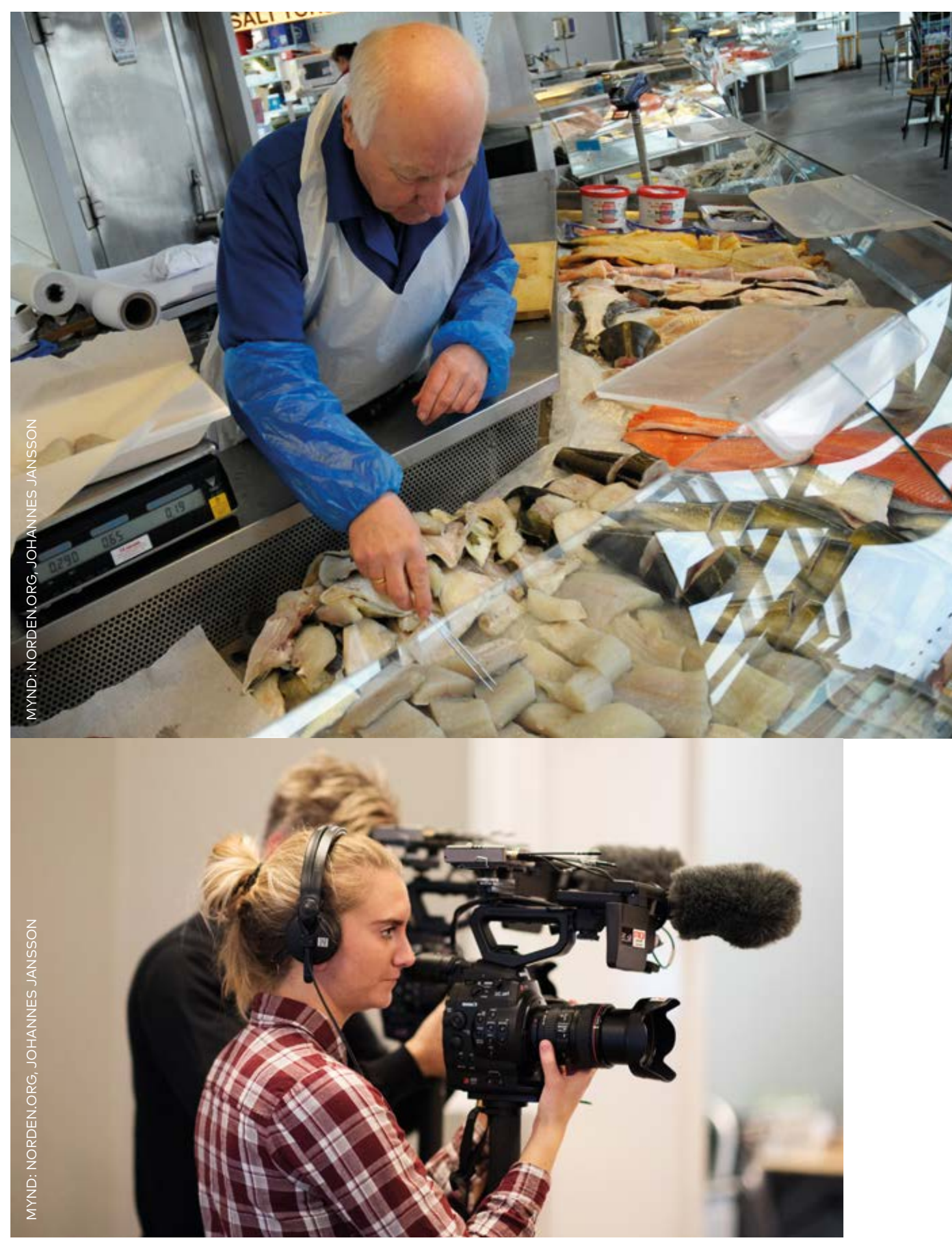


\section{Lærdi háskúlin fyri arbeiðsumhvørvi - NIVA}

Norðurlendski lærdi háskúlin fyri arbeiðsumhvørvi (NIVA) er ein norðurlendskur skúli, ið virkar undir norðurlendska samstarvinum hjá Norðurlendska ráðharraráðnum (www.niva.org). Arbeiðið hjá NIVA tekur støði i heimild, ið verður ásett av EK-A.

Høvuðsuppgávan hjá NIVA er at veita umstøður fyri, at vitan um arbeiðsheilsu og arbeiðsumhvørvi verður útbreidd. NIVA skal birta undir kjak um týdningarmikil nýskapandi arbeiðsumhvørvismál, sum kunnu betra yrkislívið í Norðurlondum. Harumframt skal NIVA skapa norðurlendskt meirvirði við at skipa fyri vísindaligum ráđstevnum, verksmiðjum og skeiðum á høgum fakligum støði - serliga á økjum, har einstøkum londum vantar neyðuga fólkagrundarlagið.

Arbeiðsheilsu- og arbeiðsumhvørvismál fevna um eitt tvørfakligt øki, hvørs avbjóðingar broytast so hvørt sum yrkislivið broytist. Serstøku avbjóðingarnar, sum standa fyri durum komandi árini, skulu endurspeglast í arbeiðinum hjá NIVA í tíðarskeiðinum fram til 2021. Tær telja til dømis: Støðugt vaksandi miðalaldur á arbeiðsføra fólkinum; sálarligar og sosialar vandar í yrkislívinum; menning av nýggjari tøkni; munadygga fyribyrging av vanlukkum í yrkislívinum; framtíðar arbeiðshættir og teirra ávirkan á arbeiðsumstøðurnar. 


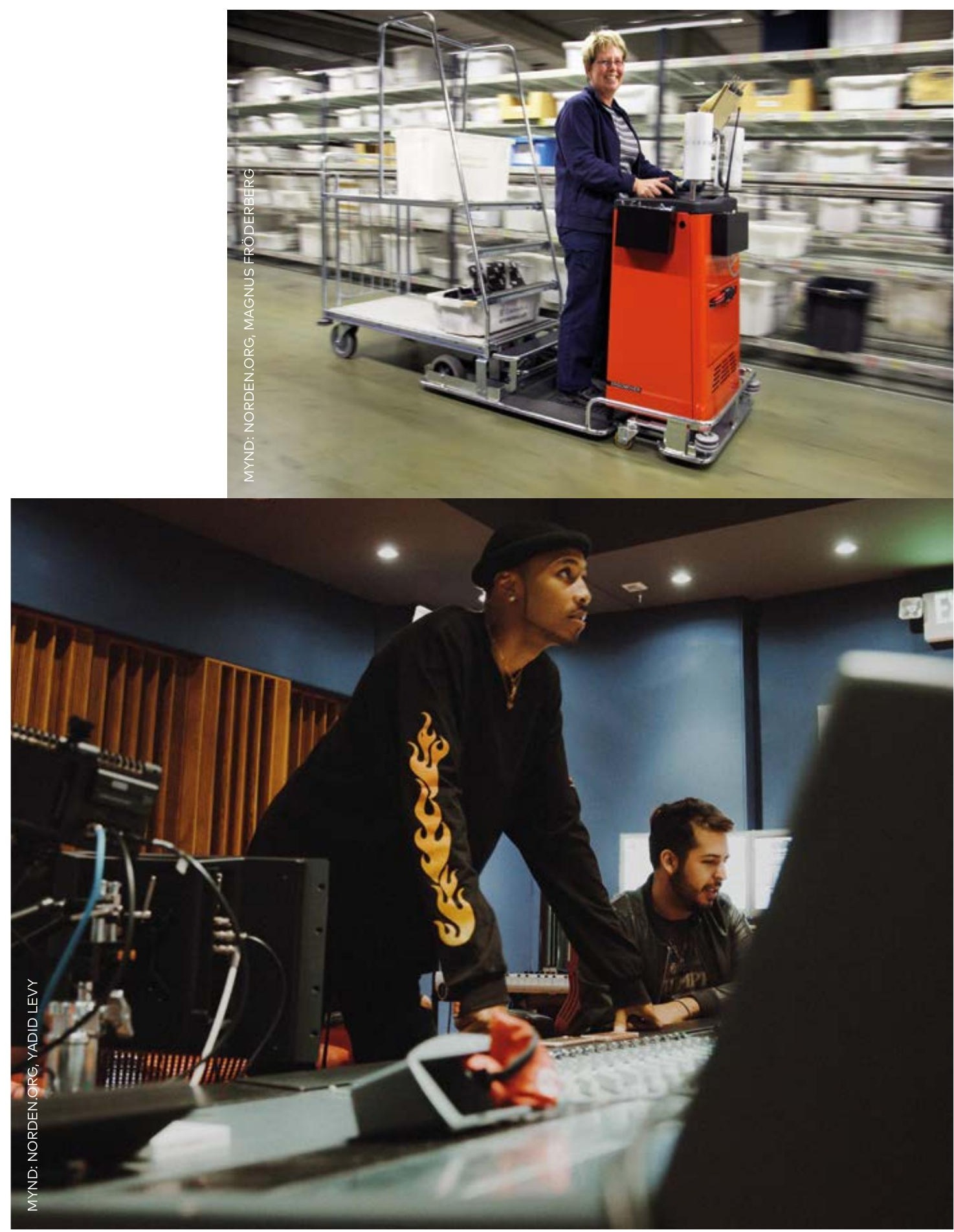




\section{Samstarvsætlanin framd í verki}

Avbjóðingarnar og átaksøkini, ið verða nevnd í hesi samstarvsætlan, verða snúningsdepil fyri norðurlendska samstarvið um yrkislívið 2018-2021.

Samstarvsætlanin endurspeglar fíggjarkarmin hjá MR-A og fer at styrkja og leggja støð̇ð undir arbeiðið hjá teimum trimum nevndunum og undir økið sum heild.

Á økinum verður serligur dentur lagdur á at varðveita eitt felags, miðvíst og tætt samskifti og sínámillum kunning, sum kann birta undir nýggja vitan og nýggj átøk. Samskifti skal vera millum fleiri partar, sum til dømis ymsu partarnar á arbeiðsmarknaðinum og granskingarbólkar umframt viðkomandi myndugleikar. Samstarvið kann til dømis geva íblástur til at menna innlendis politikk í einstøku londunum, men tað kann eisini vera ein grundvøllur fyri at samskipa sjónarmið so vítt, tað verður mett viðkomandi og gagnligt.

Samstarvsætlanin verður ítøkilig og sett í verk, serliga í sambandi við formansvirksemi og virkisætlanir hjá nevndunum. Tær føstu nevndirnar ráða yvir avmarkaðum verkætlanarpeningi, sum tær fyrst og fremst nýta til at menna vitanina um, hvussu royndir verða fluttar millum partarnar. Tað gera tær til dømis við at skráseta og greina lík og ólík tiltøk í ymsu norðurlondunum umframt úrslitini frá teimum.

Verkætlanirnar verða liðir í at fremja samstarvsætlanina í verki.

Skipað verður fyri fleiri norðurlendskum ráðstevnum um viðkomandi evni á økinum. Ráðstevnurnar leggja grundarlag undir samskifti um vitan og royndir, skapa netverk og leggja upp til fundir og menningararbeiði.

Samskiftið verður í høvuðsheitum millum MR-A, EK-A, viðkomandi nevndir og skrivstovuna hjá Norðurlendska ráðharraráonum umframt partarnar á arbeiðsmarknaðinum. Pørtunum stendur í boði at geva sítt íkast til samstarvsætlanina, og teir verða aloftast eisini bodnir til trípartasamskifti um viðkomandi evni á økinum á árliga fundinum hjá MR-A. Aðrir leikarar umframt ráð og nevndir verða eisini boðin til viðkomandi tiltøk.

Harumframt fer økið væntandi at luttaka í átøkum tvørtur um málsøki, sum verða sett í verk av til dømis forsætisráðharrunum, MR-SAM ella Norðurlandaráðnum. Samstarvsætlanin samansjóðar alt sítt virki við ætlanina fyri burðardygga menning hjá Norðurlendska ráðharraráðnum, og í 


\section{$\mathbb{1}$}

\section{Norð̆urlendska rádharrarádið}

Nordens Hus

Ved Stranden 18

1061 København K

www.norden.org

Felags arbeiðsmarknaðurin er ein hornasteinur í norðurlendska samstarvinum. Ein stór og væl útbúgvin arbeiðsmegi er týdningarmesta tilfeingi okkara, sum leggur lunnar undir ein kappingarføran norðurlendskan arbeiðsmarknað og menningina av norðurlendsku vælferðarsamfeløgunum.

Á norðurlendska arbeiðsmarknaðinum standa tó nógvar broytingar fyri durum sum avleiðing til dømis av broytingum í fólkasamansetingini, øktari altjóðagerð, tøkniligari menning og altjóða kapping.

Samstarvsætlanin fyri yrkislívið 2018-2021 vísir á mangar av hesum týðandi avbjóðingunum á økinum og lýsir, hvønn leiklut norðurlendska samstarvið kann fáa, tá ið tikið verður við hesum avbjóðingum. 